\title{
Potentiometric Determination of NAD(P)H Coenzymes Using a Nitrite-Selective Membrane Electrode and a Nitrate Reductase Enzyme and the Application to Glucose Assay in Human Serum
}

\author{
Takashi KATSU†, Takeshi HASHIMOTo and Shima HIRAMAKI \\ Faculty of Pharmaceutical Sciences, Okayama University, Tsushima, Okayama 700-8530, Japan
}

\begin{abstract}
$\mathrm{NAD}(\mathrm{P}) \mathrm{H}$ coenzyme concentrations were determined with the combination of a nitrite-selective membrane electrode and a nitrate reductase enzyme. The method was based on the detection of nitrite formed by the enzymatic reaction of $\mathrm{NAD}(\mathrm{P}) \mathrm{H}$ with nitrate catalyzed by nitrate reductase. The lower detection limits for both these coenzymes were around $100 \mu \mathrm{M}$. This system was applied to detect glucose by combining an additional glucose dehydrogenase enzyme. Serum glucose levels could be determined through the detection of nitrite.
\end{abstract}

Keywords Enzymatic method, nitrite-selective membrane electrode, nitrate reductase, NAD(P)H determination, serum glucose assay, coupled enzyme reactions

The application of ion-selective electrodes coupled with chemical reactions has recently attracted much interest, because various substances including nonionic species can easily be detected with the inherent advantages of ion-selective electrodes, i.e., high selectivity, sensitivity and freedom from optical interference. ${ }^{1-7}$ For this purpose, 1-fluoro-2,4-dinitrobenzene $^{1-4}$ and Girard's reagent ${ }^{3,5-7}$ are widely used. The former reagent can release fluoride by the reaction with amino acids, amines, hydrazines or phenols, so that a fluoride-selective electrode can be used for the determination of these compounds. The latter reagent can convert aldehydes or glucose, for example, to ionic forms which can be measured with appropriate ion-selective electrodes.

Enzyme reactions are also applied for converting biologically important substances including amino acids, phosphatidylcholine and adenosine-5'-triphosphate to suitable ionic forms. ${ }^{3,8-10}$ For example, phosphatidylcholine concentrations have been determined by detecting choline released by the enzymatic reaction of the phosphatidylcholine with phospholipase $\mathrm{D}$, using a choline-sensitive electrode. ${ }^{8}$

We are particularly interested in extending the use of various ion-selective electrodes coupled with enzymatic reactions, because this approach will lead to the detection of specific substances especially with high selectivity under mild conditions. In the present study, a nitrite-selective membrane electrode and a nitrate reductase enzyme were applied to determine the concentrations of $\mathrm{NAD}(\mathrm{P}) \mathrm{H}$ coenzymes. The method is

† To whom correspondence should be addressed. based on the following enzyme-catalyzed reaction of the coenzymes with nitrate.

$$
\mathrm{NAD}(\mathrm{P}) \mathrm{H}+\mathrm{H}^{+}+\mathrm{NO}_{3}-\stackrel{\text { Nitrate reductase }}{\longrightarrow} \underset{\mathrm{NAD}(\mathrm{P})^{+}+\mathrm{NO}_{2}{ }^{-}+\mathrm{H}_{2} \mathrm{O}}{ }
$$

Thus, the concentration of $\mathrm{NAD}(\mathrm{P}) \mathrm{H}$ can be determined through the detection of $\mathrm{NO}_{2}^{-}$. This approach is very useful because many enzyme reactions can be coupled with the formation of the coenzymes. ${ }^{11,12}$ For example, glucose can be determined when the following enzyme reaction (2) is further coupled to the reaction (1).

$$
\begin{aligned}
& \underset{\text { Glucose }+\mathrm{NAD}(\mathrm{P})^{+} \stackrel{\text { Glucose dehydrogenase }}{\longrightarrow}}{\text { Gluconolactone }+\mathrm{NAD}(\mathrm{P}) \mathrm{H}+\mathrm{H}^{+}}
\end{aligned}
$$

In this study, we noted the determination of $\mathrm{NAD}(\mathrm{P}) \mathrm{H}$ coenzymes and glucose using the combination of a nitrite-selective electrode and the above enzymatic reactions.

\section{Experimental}

\section{Reagents}

The sources of the reagents were as follows: nitrite ionophore I (aquo-cyano-cobyrinic acid-heptakis(2phenylethyl ester)) and bis(1-butylpentyl)decane-1,10diyl diglutarate (ETH 469) from Fluka (Buchs, Switzerland); poly(vinyl chloride) (PVC) (degree of polymerization, 1020) from Nacalai Tesque (Kyoto, 
Japan); nitrate reductase (from Aspergillus sp.) and glucose dehydrogenase $\left(\mathrm{NADP}^{+}\right.$dependent, from Cryptococcus uniguttulatus) from Sigma (St. Louis, $\mathrm{MO}, \mathrm{USA}$ ); and NADPH, NADH and $\mathrm{NADP}^{+}$from Oriental Yeast (Tokyo, Japan). All other chemicals used were of analytical-reagent grade.

\section{Electrode system}

The nitrite-selective electrode was constructed similarly to that reported previously. ${ }^{13,14}$ The components of the sensor membrane were $2 \mathrm{mg}$ of nitrite ionophore I, $60 \mu \mathrm{l}$ of ETH 469 and $30 \mathrm{mg}$ of PVC. The materials were dissolved in tetrahydrofuran (about $1 \mathrm{ml}$ ) and poured into a flat Petri dish (16 $\mathrm{mm}$ diameter), then the solvent was evaporated at room temperature. The resulting membrane was excised and attached to a PVC tube (4 $\mathrm{mm}$ o.d., $3 \mathrm{~mm}$ i.d.) with tetrahydrofuran adhesive. In the present study, a small-sized dish was used to make the sensor membrane instead of an ordinarysized (28 mm diameter) one ${ }^{8-10}$, because the response characteristics of the electrode were remarkably improved. The PVC tube was filled with an internal solution comprising $10 \mathrm{mM} \mathrm{NaNO}_{2}$ and $10 \mathrm{mM} \mathrm{NaCl}$, and the sensor membrane was conditioned overnight. The electrochemical cell arrangement was

$\mathrm{Ag}, \mathrm{AgCl} /$ internal solution/sensor membrane/sample solution/1 $\mathrm{M} \mathrm{NH}_{4} \mathrm{NO}_{3}$ (salt bridge) $/ 10 \mathrm{mM}$ $\mathrm{KCl} / \mathrm{Ag}, \mathrm{AgCl}$.

The electromotive force (emf) between the silver/silver chloride electrodes was measured using a voltmeter with high input impedance produced by a field-effect transistor operational amplifier (LF356; National Semiconductor, Sunnyvale, CA, USA; input resistance $>10^{12} \Omega$ ) and was recorded. The detection limit was defined as the intersection of the extrapolated linear regions of the calibration graph. ${ }^{15}$ All measurements were performed at a constant temperature of $25^{\circ} \mathrm{C}$.

\section{Determination of $N A D(P) H$}

Standard aqueous solutions of $\mathrm{NAD}(\mathrm{P}) \mathrm{H}$ coenzymes in the range of $1 \times 10^{-6}-1 \times 10^{-2} \mathrm{M}$ were prepared. To $100 \mu \mathrm{l}$ of the standard solution, $50 \mu \mathrm{l}$ of an assay solution containing $0.1 \mathrm{U}$ nitrate reductase, $150 \mathrm{mM}$ $\mathrm{NaNO}_{3}$ and $30 \mathrm{mM} \mathrm{NaH} \mathrm{PO}_{4} / \mathrm{Na}_{2} \mathrm{HPO}_{4}(\mathrm{pH}$ 7.4) was added, and the mixture was incubated at $25^{\circ} \mathrm{C}$ for 10 min. Subsequently, $50 \mu \mathrm{l}$ of $500 \mathrm{mM} \mathrm{NaH} \mathrm{PO}_{4} / \mathrm{Na}_{2} \mathrm{HPO}_{4}$ (pH 5.0) was introduced to adjust the $\mathrm{pH}$ of the solution to around 5, and the nitrite formed was measured using the nitrite-selective electrode. It should be emphasized that the present electrode system, including the reference electrode ${ }^{16}$, is compact, and therefore, assay solution volumes as small as $200 \mu \mathrm{l}$ can be used. Between measurements, the nitrite electrode was soaked in distilled water for $20-30 \mathrm{~s}$, rinsed several times with distilled water and wiped. The electrode was stored in 10 $\mathrm{mM} \mathrm{NaNO}_{2}$ and $10 \mathrm{mM} \mathrm{NaCl}$ when not in use.

\section{Determination of glucose}

To $100 \mu \mathrm{l}$ of the standard aqueous solution containing
$1 \times 10^{-6}-1 \times 10^{-2} \mathrm{M}$ glucose, $50 \mu \mathrm{l}$ of an assay solution containing $0.1 \mathrm{U}$ nitrate reductase, $150 \mathrm{mM} \mathrm{NaNO}_{3}, 0.5$ U glucose dehydrogenase, $0.5 \mathrm{mM} \mathrm{NADP}{ }^{+}$and $30 \mathrm{mM}$ $\mathrm{NaH}_{2} \mathrm{PO}_{4} / \mathrm{Na}_{2} \mathrm{HPO}_{4}$ ( $\mathrm{pH}$ 7.4) was added, the mixture was incubated at $25^{\circ} \mathrm{C}$ for $10 \mathrm{~min}$, and $50 \mu \mathrm{l}$ of 500 $\mathrm{mM} \mathrm{NaH} \mathrm{PO}_{4} / \mathrm{Na}_{2} \mathrm{HPO}_{4}$ (pH 5.0) was introduced. Then, the nitrite formed was determined by the electrode as described above. The determination of glucose in human serum was performed after the serum $(20 \mu \mathrm{l})$ was initially diluted with distilled water to $100 \mu$ l. The glucose level in serum was calculated by subtracting the blank level of $\mathrm{NO}_{2}{ }^{-}$which was produced in the absence of glucose dehydrogenase. The glucose concentration in serum was also determined by a colorimetric method using a reagent kit available from Iatron Laboratories (Iatro-Chrom GLU-L $\mathrm{Q}_{\mathrm{Q}}$; Tokyo, Japan).

\section{Results and Discussion}

\section{Response characteristics of the electrode}

The potentiometric response of the nitrite-selective electrode was first examined in buffer solutions consisting of $100 \mathrm{mM} \mathrm{NaH} \mathrm{PO}_{4} / \mathrm{Na}_{2} \mathrm{HPO}_{4}(\mathrm{pH} 7.4$ and $\mathrm{pH}$ 5). The calibration graphs were obtained by measuring known amounts of sodium nitrite added to the buffers and plotting the concentrations against the corresponding emf values obtained. As shown in Fig. 1, the electrode responded to nitrite more sensitively at acidic $\mathrm{pH}$ 5 than at $\mathrm{pH}$ 7.4. The slope of the electrode response and the lower limit of detection at $\mathrm{pH} 7.4$ were $-46 \mathrm{mV}$ per concentration decade and $300 \mu \mathrm{M}$, respectively, while those at $\mathrm{pH} 5$ were $-57 \mathrm{mV}$ per concentration decade and $8 \mu \mathrm{M}$, respectively. The low sensitivity of the electrode at higher $\mathrm{pH}$ is shown to be due to large

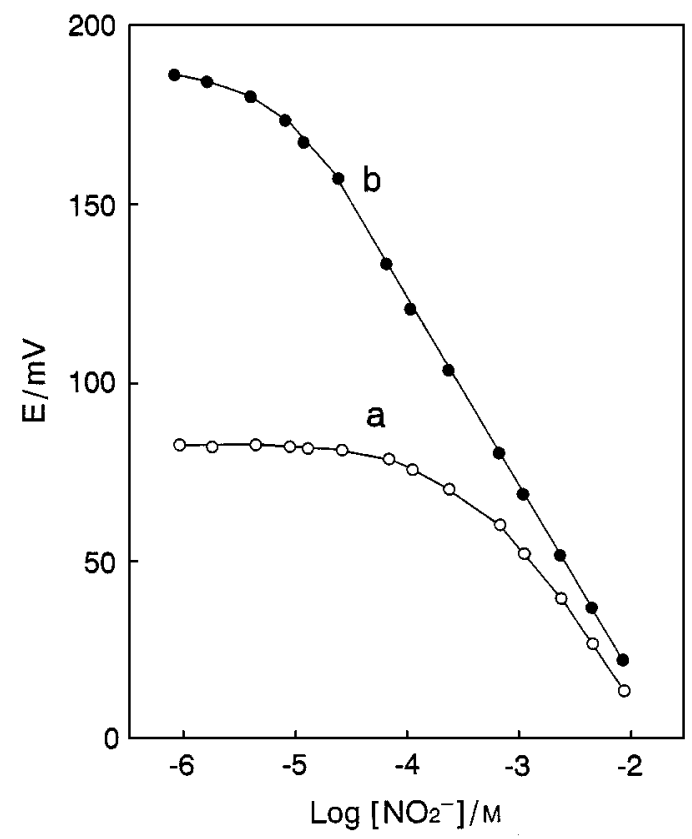

Fig. 1 Response to nitrite at $\mathrm{pH} 7.4$ (line a) and $\mathrm{pH} 5$ (line b). 


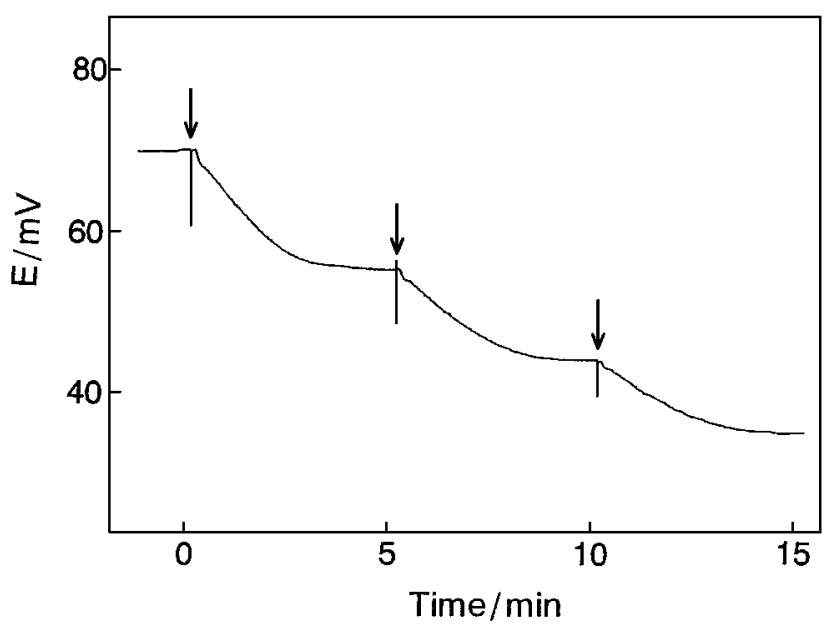

Fig. 2 Response to NADPH in an assay solution $(200 \mu \mathrm{l})$ containing $0.1 \mathrm{U}$ nitrate reductase, $50 \mathrm{mM} \mathrm{NaNO}$ and $10 \mathrm{mM}$ $\mathrm{NaH}_{2} \mathrm{PO}_{4} / \mathrm{Na}_{2} \mathrm{HPO}_{4}$ (pH 7.4). At the time indicated by the arrow, $1 \mu \mathrm{l}$ of $100 \mathrm{mM}$ NADPH was added (corresponding to $0.5 \mathrm{mM}$ NADPH when diluted in the assay solution).

interference from hydroxide ion. ${ }^{17}$ The nitrite electrode is reported to be free from interference from various anions including phosphate, nitrate and chloride, but the hydroxide ion is an exception. ${ }^{13,14}$

In order to confirm directly whether the concentration of the coenzyme can be determined through the detection of nitrite, we monitored the time response of the enzyme reaction of NADPH and nitrate reductase. A typical chart of the response to NADPH is shown in Fig. 2. When $1 \mu \mathrm{l}$ of $100 \mathrm{mM}$ NADPH aqueous solution (final concentration: $0.5 \mathrm{mM}$ ) was added at the time indicated by the first arrow to an assay solution $(200 \mu \mathrm{l})$ containing $0.1 \mathrm{U}$ nitrate reductase, $50 \mathrm{mM}$ $\mathrm{NaNO}_{3}$ and $10 \mathrm{mM} \mathrm{NaH} \mathrm{PO}_{4} / \mathrm{Na}_{2} \mathrm{HPO}_{4}(\mathrm{pH} 7.4)$, a rapid response was observed and the final potential level reached corresponded to $0.5 \mathrm{mM}$ nitrite. The same amount of NADPH was added again at the times indicated by the second and third arrows, and these potential levels also corresponded to $1.0 \mathrm{mM}$ and 1.5 $\mathrm{mM}$ nitrite, respectively. This result demonstrated clearly that the present system is suitable for determining the concentration of coenzyme; however, one problem that remained was the low sensitivity of the electrode at $\mathrm{pH}$ 7.4. We performed measurements at $\mathrm{pH} 5$, at which electrode response was improved remarkably as shown in Fig. 1. At this pH, however, the enzyme did not work. Thus, the assay sample was acidified after the enzyme reaction at $\mathrm{pH}$ 7.4. According to the procedure described in the experimental section, we constructed calibration graphs of the NADPH and NADH coenzymes. As shown in Fig. 3, NADPH showed a near-Nernstian response (line a) with a slope of $-57 \mathrm{mV}$ per concentration decade except for the higher concentration range of 5 to $10 \mathrm{mM}$, while NADH showed a much worse response (line b). The lower limits of detection for both these coenzymes were around $100 \mu \mathrm{M}$. The deviation from the linear

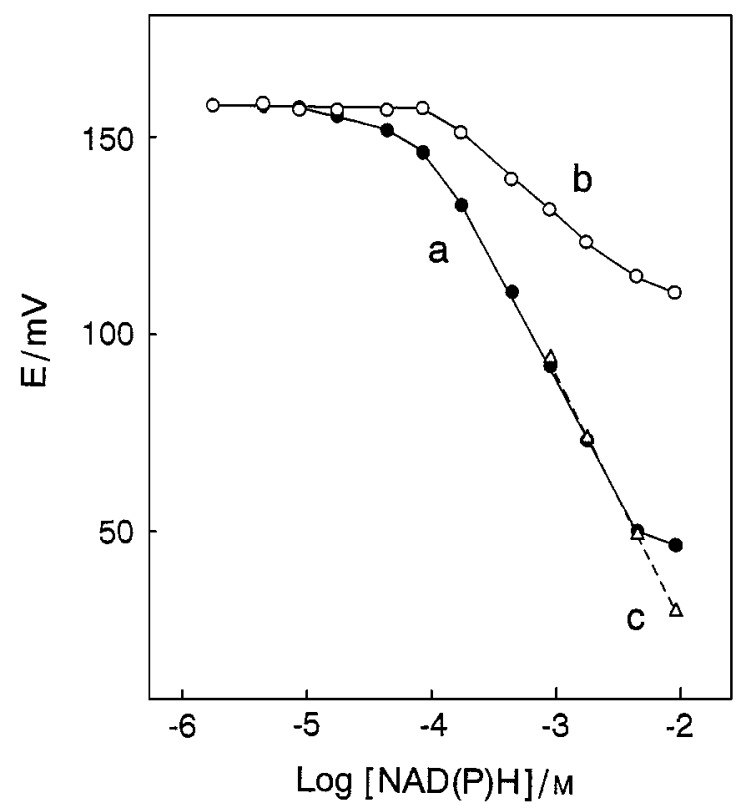

Fig. 3 Calibration graphs for NADPH (line a) and NADH (lines $\mathrm{b}$ and $\mathrm{c}$ ). In line $\mathrm{c}$, the enzymatic reaction with $\mathrm{NADH}$ proceeded completely.

response at high concentration of NADPH would be induced by the product inhibition due to the high accumulation of $\mathrm{NADP}^{+}$in the reaction system, and this will be discussed further in the next section. The lower sensitivity to NADH than to NADPH indicated the lower reactivity to $\mathrm{NADH}$ on the nitrate reductase of Aspergillus sp. used in the present study. When the reaction time was prolonged from $10 \mathrm{~min}$ to $60 \mathrm{~min}$ and the enzyme unit increased from $0.1 \mathrm{U}$ to $0.5 \mathrm{U}$, the calibration graph of NADH (line c) was almost superimposed on that of NADPH (line a), except that the linear response was further prolonged even at high concentration $(10 \mathrm{mM})$ of NADH over the case of NADPH.

\section{Determination of glucose using coupled enzyme reactions}

Then, we determined glucose concentrations, using the coupled enzyme reactions (1) and (2) shown in the introduction. In the reaction of glucose with $\mathrm{NADP}^{+}$ catalyzed by glucose dehydrogenase, $\mathrm{NADP}^{+}$is converted to NADPH which is, in turn, the substrate of nitrate reductase. Thus, $\mathrm{NADP}^{+}$will be regenerated and available for the glucose dehydrogenase again. This indicates that the amount of $\mathrm{NADP}^{+}$initially added can be suppressed. To determine the optimum concentration of $\mathrm{NADP}^{+}$in this system, we examined the concentration dependence of the coenzyme on potential response (Fig. 4). It was found that glucose was efficiently converted to nitrite even at the low concentration of $\mathrm{NADP}^{+}(0.2-1 \mathrm{mM}$ showing the concentration contained in $50 \mu \mathrm{l}$ assay solution defined in the experimental section). This demonstrated that the enzyme recycling occurred effectively as discussed above. In contrast, when $\mathrm{NADP}^{+}$concentrations increased up to $10 \mathrm{mM}$, the conversion did not effec- 


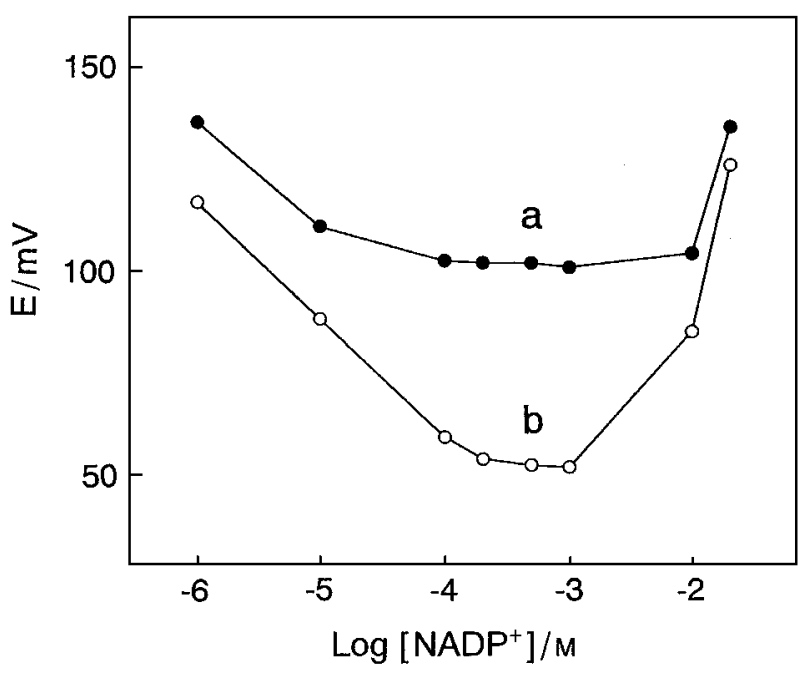

Fig. 4 Effect of $\mathrm{NADP}^{+}$concentration on potential response. Glucose concentrations were $1 \mathrm{mM}$ (line a) and $10 \mathrm{mM}$ (line b); these were contained in initial standard solution $(100 \mu \mathrm{l})$, while the $\mathrm{NADP}^{+}$concentrations shown in the abscissa were those contained in assay solution $(50 \mu \mathrm{l})$. See the experimental section for the definition of standard and assay solutions.

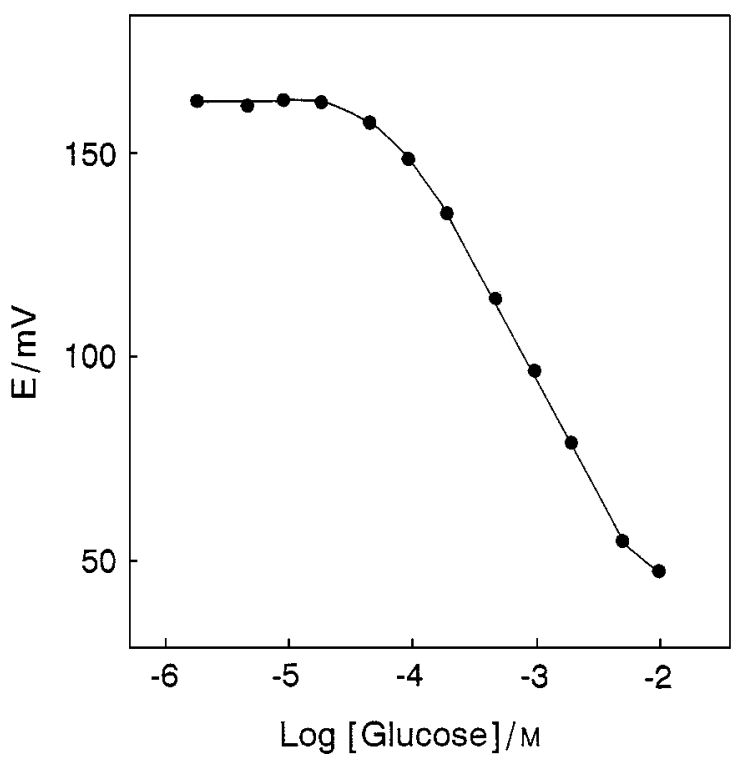

Fig. 5 Calibration graph for glucose.

tively proceed, suggesting that the enzyme activity of nitrate reductase was affected significantly in the presence of a large amount of $\mathrm{NADP}^{+}$. This was consistent with a decrease in potential change at high concentration of NADPH observed in Fig. 3 (line a), where a large amount of $\mathrm{NADP}^{+}$was formed in the reaction mixture, leading to so-called product inhibition. Thus, we added $0.5 \mathrm{mM} \mathrm{NADP}{ }^{+}$to make the calibration graph for glucose. As shown in Fig. 5, the calibration graph for glucose was similar to that for NADPH, and glucose could be determined down to $100 \mu \mathrm{M}$.

We determined serum glucose levels using this method, because the nitrite electrode suffered no serious interference from $\mathrm{Cl}^{-}, \mathrm{HCO}_{3}{ }^{-}$or other anions pre-
Table 1 Glucose concentrations in serum samples determined by potentiometry and by colorimetry

\begin{tabular}{cccccc}
\hline \multirow{2}{*}{$\begin{array}{c}\text { Serum } \\
\text { sample }\end{array}$} & \multicolumn{2}{c}{ Potentiometry } & & \multicolumn{2}{c}{ Colorimetry } \\
\cline { 2 - 3 } \cline { 5 - 6 } & Glucose $/ \mathrm{mM}$ & RSD, \% & & Glucose $\mathrm{a} / \mathrm{mM}$ & $\mathrm{RSD}, \%$ \\
\hline 1 & 4.4 & 2.6 & & 4.2 & 2.9 \\
2 & 5.0 & 2.0 & & 5.0 & 3.2 \\
3 & 5.2 & 2.3 & & 5.0 & 3.4 \\
\hline
\end{tabular}

a. Average of three experiments.

sent in biological fluids. ${ }^{13,14}$ The normal range of glucose was reported to be $3.3-5.6 \mathrm{mM} .{ }^{18}$ Table 1 summarizes the results in three different donors determined by the present method, along with those obtained by colorimetry. The glucose levels estimated by the present method showed similar values to those obtained by colorimetry.

These results demonstrate that the combination of the nitrite electrode and enzyme reactions involving nitrate reductase is useful for the determination of coenzyme and glucose concentrations. Since there are many enzymatic reactions coupled with $\mathrm{NADP}^{+}$(or $\left.\mathrm{NAD}^{+}\right)^{11,12}$, the present system can be applied for the determination of various biologically important substances.

This work was supported by a Grant-in-Aid from the Research Foundation on Development of Chemical Materials and a Grant-in-Aid for Scientific Research from the Ministry of Education, Science, Sports and Culture of Japan.

\section{References}

1. E. Athanasiou-Malaki and M. A. Koupparis, Analyst [London], 112, 757 (1987).

2. E. Athanasiou-Malaki, M. A. Koupparis and T. P. Hadjiioannou, Anal. Chem., 61, 1358 (1989).

3. V. V. Cosofret and R. P. Buck, Crit. Rev. Anal. Chem., 24, 1 (1993).

4. S. S. M. Hassan, E. H. El-Naby and E. M. Elnemma, Mikrochim. Acta, 124, 55 (1996).

5. W. H. Chan, P. X. Cai and X. H. Gu, Analyst [London], 119, 1853 (1994).

6. W. H. Chan and R. Yuan, Analyst [London], 120, 1055 (1995).

7. W. H. Chan, Y. L. Wong-Leung, T. F. Lai and R. Yuan, Anal. Lett., 30, 45 (1997).

8. T. Katsu, M. Kuroko, T. Hirota and Y. Fujita, Anal. Chim. Acta, 217, 193 (1989).

9. T. Katsu, T. Kayamoto and Y. Fujita, Anal. Chim. Acta, 239, 23 (1990).

10. T. Katsu and K. Yamanaka, Anal. Chim. Acta, 276, 373 (1993).

11. M. Dixon and E. C. Webb, "Enzymes”, 3rd ed., Longman, London, 1979.

12. C. H. Suelter, "A Practical Guide to Enzymology", Wiley, New York, 1985. 
13. D. Ammann, M. Huser, B. Kräutler, B. Rusterholz, P Schulthess, B. Lindemann, E. Halder and W. Simon, Helv. Chim. Acta, 69, 849 (1986).

14. R. Stepánek, B. Kräutler, P. Schulthess, B. Lindemann, D. Ammann and W. Simon, Anal. Chim. Acta, 182, 83 (1986).

15. G. G. Guilbault, Ion-Sel. Electrode Rev., 1, 139 (1979).

16. T. Katsu, H. Kobayashi and Y. Fujita, Biochim. Biophys. Acta, 860, 608 (1986).
17. P. Schulthess, D. Ammann, B. Kräutler, C. Caderas, R. Stepánek and W. Simon, Anal. Chem, 57, 1397 (1985).

18. T. Usui, T. Sasaki and A. Kohsaka, "Rinsho Kagaku (Clinical Chemistry, in Japanese)", 3rd ed., Igaku Shoin, Tokyo, 1992.

(Received October 13, 1998)

(Accepted December 9, 1998) 